\title{
Aspectos Inconstitucionais do Controle Externo da Polícia Judiciária ${ }^{1}$
}

\author{
Guilherme Cunha Werner²
}

\begin{abstract}
RESUMO
O controle externo das atividades de Polícia Judiciária deve ser exercido dentro do estrito balizamento constitucional, caso contrário, comprometerá a atividade de investigação criminal, o acesso paritário das partes à Justiça e a transparência dos órgãos públicos, consequências extremamente gravosas para a estabilidade das estruturas do Estado Democrático de Direito. Pretende-se com está reflexão fazer um alerta sobre a necessidade de se restabelecer o papel originário das instituições de Estado, uma vez que, a interpretação ampla e extensiva dada às resoluções expedidas pelos Conselhos dos Ministérios Públicos, distorce a essência da atividade da investigação em três perspectivas distintas: a) fortalece a ingerência do Poder Executivo; b) afasta a apreciação do Poder Judiciário e, por conseguinte o controle de legalidade;
\end{abstract}

1 O tema é recorrente e surge a partir dos debates ocorridos no dia 27 de Outubro de 2015 em Brasília no Seminário "A Construção de uma Polícia Republicana: Autonomia, Eficiência e Imparcialidade", como decorrência do Grupo de Pesquisa da Escola Superior de Polícia intitulado "Sistemas de justiça penal, Polícia Judiciária e investigação criminal", desenvolvido em nosso texto "Isenção Política na Polícia Federal: A autonomia em suas dimensões administrativa, funcional e orçamentaria", publicado na Edição Especial da Revista Brasileira de Ciências Policiais, v. 6, n.2, jul-dez de 2015, que pode ser consultada em: https://periodicos.pf.gov.br/index. php/RBCP/article/viewFile/383/247 Visitado em 10.07.2016 e nesta ocasião mereceu especial atenção e destaque, sendo agora a atenção individualizada no tocante ao uso político do controle externo da Polícia Judiciária pelos Ministérios Públicos Estaduais e da União.

2 Doutor e mestre em Ciência Política FFLCH/USP e Pós-doutorado em Direito Penal FD/USP, com orientação da Profa. Janaina Conceição Paschoal; pesquisador do Núcleo de Políticas Públicas da Universidade de São Paulo NUPPS/USP; Presidente do Conselho Científico do Observatório de Criminalidade Organizada (OB-COR) da Escola Superior de Polícia (Academia Nacional de Polícia), onde também é professor do programa de pós-graduação. Delegado da Polícia Federal aposentado. 
e c) possibilita a invasão da competência constitucional por meio de procedimentos de investigação seletiva.

SUMÁRIO: 1. Introdução: Dimensões do Controle; 1.1. A origem do controle externo; 1.2. A criação dos Conselhos; 2. Problemas do controle feito pelo Ministério Público; 2.1. In gerencia do Poder Executivo; 2.2. Seletividade na investigação; 2.3. Afastamento do controle do Poder Judiciário; 3 . Conclusões; Bibliografia.

\section{InTROduÇão: Dimensão do CONTROLE}

A dimensão do controle institucional é identificada no conjunto de intervenções, positivas e negativas, acionadas por cada sociedade, grupo social, indivíduo ou instituição, com a finalidade de influir nas ações de determinado grupo ou instituição, com o fim de prevenir e impedir o desvio de conduta e, assim, adotar medidas destinadas ao restabelecimento das condições de conformação com as normas, obedecendo a um caráter propositivo e regenerador das ações do Estado e da sua capacidade de resolução dos conflitos de forma transparente e igualitária, garantindo assim a segurança jurídica e a estabilidade social.

A dimensão do controle das atividades públicas pode ser expressa de duas formas distintas:

a) Prestação de Contas (Accountability): conceito da Ciência Política que expressa a ideia de controle e configura-se na obrigação dos integrantes dos órgãos públicos e representantes políticos de prestarem contas às instâncias controladoras bem como à população das suas atividades, dando a necessária transparência impositiva da responsabilidade democrática de informar as decisões e ações, passadas e futuras, com a consequente responsabilização por eventual desvio de conduta, sendo uma resposta substantiva apresentada não apenas para os detentores do poder, mas também para todos os seus representantes (Melo, 2007: 11-29 e Schedler, 1999: 13- 
28). Atualmente o tema guarda conexão com o direito de acesso à informação, o que denota a inclusão da noção de que a comunicação entre o Estado e seus cidadãos deve ocorrer de forma clara e acessível a permitir que o cidadão possa conferir os dados e utilizá-los para análises e propostas de melhoramento do sistema, possibilitando assim a formação de um sistema constante de participação e retroalimentação (input e output) servindo inclusive de crítica ao modelo proposto por Schumpeter (Habermas, 1996: 330-334);

b) Capacidade de Resposta (Responsiveness): refere-se à habilidade específica de atendimento às demandas formuladas e às propostas estabelecidas na agenda política, não apenas por meio de respostas retóricas feitas descritas nos programas políticos, mas também na forma efetiva e eficaz em definir as prioridades orçamentárias, é a resposta democrática no tocante a forma como políticos priorizam as diferentes agendas e o grau de correspondência destas com as preferências públicas. (Peterson, Gerard e Guido, 1997: 1163-1165).

Ambas compõem o essencial mecanismo democrático de participação popular, em que os representantes do povo participam diretamente da condução do país influindo no desenho das políticas públicas, na formulação de suas preferências manifestas livremente e fundadas na garantia do acesso a diversidade das fontes de informação confiáveis, claras e transparentes. (DHAL, 1997: 08-09).

As instituições de governo em uma democracia não podem ser consideradas como neutras ou indeterminadas, muito menos genéricas, devem estar inseridas em um sistema que possibilite às avaliações e controles do seu desempenho de forma a possibilitar a aferição do grau de eficiência no cumprimento da missão constitucionalmente prescrita, sendo a expressão da garantia da liberdade e igualdade entre os cidadãos, bases fun- 
damentais do direito e da cidadania, e assim assegurar a universalidade, impessoalidade, probidade e justiça das suas ações (OFFE, 2001: 73-76).

A democracia é o exercício do justo equilíbrio entre os legítimos valores a ela concernentes, na qual a polícia se encontra inserida na mesma dinâmica de equilíbrio com outras instituições governamentais, ao desempenhar suas competências e atribuições em conformidade com as normas constitucionais e legais, em um ambiente onde a competência funcional proíbe a sobreposição do exercício das atribuições de uma instituição sobre a outra.

\subsection{A ORIGEM DO CONTROLE EXTERNO}

O debate político da Assembleia Constituinte de 1986/88 estabeleceu o controle externo das atividades de determinados entes estatais por outros como expressão do equilíbrio entre os poderes, assim o Município pelo Poder Legislativo municipal (art. 31), as entidades da administração direta e indireta pelo Congresso Nacional e Tribunal de Contas (arts. 70 e 74), sendo tal controle exercido em todos os níveis, até o Presidente da República no cumprimento das leis orçamentárias (art.85 VI), exemplos de um sistema em que quem exerce a competência é fiscalizado por outro que não a exerce.

Ainda que o ponto central do debate político tenha gravitado ao redor da necessidade de superação do regime de exceção posto pelo governo militar (1964/1985), o Constituinte também trabalhava influenciado pela retórica da justificativa de se evitar o arbítrio ocorrido por parte dos órgãos de segurança pública, e neste contexto, foi criado o controle externo da atividade de polícia judiciária a cargo Ministério Público , anteriormente órgão da composição do Poder Judiciário (Constituição Federal de 1967) e 
reposicionado como função essencial à justiça ladeado pela advocacia pública e privada e pela defensoria pública, apesar deste conjunto, apenas ao ente ministerial foi dado o exercício de tal controle.

A agenda política da época também contemplava a reforma das estruturas do Poder Judiciário, tendo por pano de fundo a necessidade da democratização no acesso à justiça e na superação da morosidade das decisões judiciais, algo historicamente observado desde a célebre frase de Rui Barbosa em 1921: “justiça atrasada não é justiça, senão injustiça qualificada e manifesta. Porque a dilação ilegal nas mãos do julgador contraria o direito das partes, e, assim, as lesa no patrimônio, honra e liberdade"3 uma crítica aberta às estruturas herdadas do Brasil Império, tendo o debate entretanto perdido fôlego diante dos questionamentos postos pela abertura política e fundados no receio do retrocesso nas questões referentes a anistia aos crimes políticos.

\subsection{A CRIAÇÃO DOS CONSELHOS}

Não se foge da história, assim não tardou para o modelo constitucional proposto entrar em crise, a questão da reforma institucional e do judiciário retorna ao centro do debate político na forma da Proposta de Emenda Constitucional PEC n.․․ 96/1992 ${ }^{4}$ ao estabelecer os fundamentos da democratização do acesso a justiça, sendo seguida em um curto espaço de tempo de dois anos pela PEC n.. 173/1995, destinada a reforma da admi-

3 A Constituição Federal estabelece como função institucional do Ministério Público o exercício do controle externo da atividade policial, na forma da lei complementar no âmbito da União e dos Estados, cuja iniciativa é facultada aos respectivos ProcuradoresGerais na forma da organização, atribuição e estatuto de cada Ministério Público (Art. $129 \mathrm{VII}$ c/c 128 \& $\left.5^{\circ} \mathrm{CF} / 1988\right)$.

4 Neste sentido a Exposição de Motivos da Reforma do Poder Judiciário (PEC n.․․ 96/1992) de autoria do Deputado Federal Hélio Bicudo traz o apanhado histórico dos problemas e mazelas do Poder Judiciário http://www.camara.gov.br/proposicoesWeb/ fichadetramitacao?idProposicao=14373 Visitado em 10.08.2016. 
nistração pública como um todo, tendo por pano de fundo revigorar a capacidade de gestão e de retomada do desenvolvimento econômico com a superação da crise fiscal, raiz da estagnação do país dos últimos quinze anos, ou seja, desde 1980 já estavam postos os problemas ainda atuais e que a Assembleia Constituinte de 1986/88 não enfrentou ou não teve a vontade de enfrentar ${ }^{5}$.

A proposta da reforma administrativa foi a primeira a ser convertida na Emenda Constitucional n. ${ }^{\circ} 19$ no ano de 1998, entretanto, apenas após a mudança da conjuntura econômica global e das pressões internacionais de órgãos como o Banco Mundial ${ }^{6}$ - advertindo da necessidade da reforma do judiciário dotando-o de instrumentos de transparência e controle (accountability), com o objetivo de possibilitar a pronta resolução dos conflitos de forma igualitária tanto para os cidadãos, quanto para os agentes econômicos (responsiveness), com o escopo de garantir a segurança e estabilidade jurídica - é que a proposta foi convertida na Emenda Constitucional n. ${ }^{\circ}$ 45, no ano de 2004.

Nesse contexto político nasceram os Conselhos Nacionais da Justiça (CNJ) e do Ministério Público (CNMP), instituições de inspiração nórdico-europeu ${ }^{7}$ de controle institucional com com-

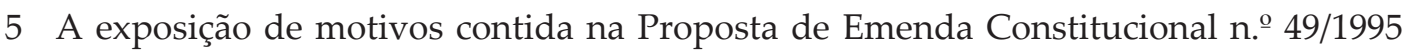
de reforma administrativa é clara em apontar que os problemas da administração pública encontram-se fundados no "enfoque equivocado que levou ao desmonte do aparelho estatal e ao desprestígio de sua burocracia". Disponível em: http://www. camara.gov.br/proposicoesWeb/prop_mostrarintegra;jsessionid=5C81D5A7A6C6C 112DEC999BCCDEC5E96. proposicoesWeb2? codteor=1242603\&filename=Dossie+PEC+173/1995. Visitado em 10.07.2016.

6 O Banco Mundial em 1996 publicou o Documento Técnico n. 319 indicando os elementos necessários a uma reforma do setor judiciário na América Latina e Caribe. Disponível em: http://w1.cejamericas.org/index.php/biblioteca/biblioteca-virtual/ doc_view/4487-the-judicial-sector-in-latin-america-and-the-caribbean-elements-ofreform-pdf,-5-2-mb.html. Visitado em 10.07.2016.

7 A matriz do Conselho Nacional de Justiça segue uma tendência internacional iniciada na Itália e França e em países do norte da Europa, neste sentido José Adércio Leite Sampaio O Conselho Nacional de Justiça e a independência do Poder Judiciário. Belo Horizonte: Del Rey, 2007. 
posição colegiada e participação democrática de diversos ramos da sociedade, cujas decisões proferidas não apresentam um caráter jurisdicional nem tampouco normativo ${ }^{8}$, apenas limitando-se ao plano interno institucional de observância e ao cumprimento dos deveres e obrigações legais, na ordem administrativo-funcional, prevendo inclusive a possibilidade do recebimento de reclamações e denúncias relativas aos seus integrantes com previsão de pronto encaminhamento ao controle interno dos órgãos exercido pelas respectivas corregedorias.

Cabe destacar que a composição colegiada se demonstrou, na prática, pouco representativa, na proporção de um 1/4 (um quarto) dos integrantes pertencentes aos quadros da Ordem dos Advogados e da sociedade civil e, o restante da própria instituição ou a instituição correlata de controle ${ }^{9,10}$, e mesmo com tal distorção, é possível identificar uma importante medida adotada pela Resolução de nº 07/2005 do CNJ que proíbe a contratação de parentes, até

8 O Supremo Tribunal Federal decidiu neste sentido, conforme Ação Direta de inconstitucionalidade ADIN n.o 3.367-DF disponível em: http://stf.jusbrasil.com.br/ jurisprudencia/765314/acao-direta-de-inconstitucionalidade-adi-3367-df. Visitado em 10.07.2017.

9 O Conselho Nacional de Justiça CNJ é composto por quinze membros eleitos por dois anos, permitida apenas uma recondução, salvo o Presidente, nove escolhidos dentre os representantes da própria instituição nas esferas Federal e Estatual, observados critérios específicos de designação dos seis demais escolhidos dois são oriundos dos Ministérios Públicos, e o restante, ou seja apenas quatro da sociedade civil, sendo dois advogados indicados pelo Conselho Federal da Ordem dos Advogados e dois cidadãos de notável saber jurídico e reputação ilibada, indicados um pela Câmara dos Deputados e outro pelo Senado Federal (art. 103-B CF/1988 com redação dada pela Emenda Constitucional n. ${ }^{-15 / 2004}$ com modificações efetuadas pela Emenda Constitucional n.․ 61/2009).

10 O Conselho Nacional do Ministério Público CNMP apresenta uma composição de quatorze membros eleitos por dois anos, permitida apenas uma recondução, sendo oito escolhidos dentre os representantes da própria instituição nas esferas Federal e Estatual, observados critérios específicos de designação dos seis demais membros escolhidos em pares dentre os integrantes do Poder Judiciário, restando apenas quatro, sendo dois advogados indicados pelo Conselho Federal da Ordem dos Advogados e dois cidadãos de notável saber jurídico e reputação ilibada, indicados um pela Câmara dos Deputados e outro pelo Senado Federal (art. 130-A CF/1988 com redação dada pela Emenda Constitucional n. ${ }^{\circ}$ 45/2004). 
o terceiro grau, para cargos de chefia, direção e assessoramento vedando a prática do nepotismo e nepotismo cruzado $^{11}$.

Importante destacar que passou desapercebido na Emenda Constitucional n. ำ 19/1998 a supressão do artigo 241 das Disposições Constitucionais Gerais que determinava expressamente que "aos delegados de polícia de carreira aplica-se o princípio do art. 39, $\S 1^{\underline{0}}$, (isonomia de vencimentos) correspondente às carreiras disciplinadas no art. 135 (funções essenciais à Justiça) desta Constituição.", e sua substituição por outro que trata de matéria completamente diversa, Art. 241. "A União, os Estados, o Distrito Federal e os Municípios disciplinarão por meio de lei os consórcios públicos e os convênios de cooperação entre os entes federados, autorizando a gestão associada de serviços públicos, bem como a transferência total ou parcial de encargos, serviços, pessoal e bens essenciais à continuidade dos serviços transferidos." o que gerou a distorção nos vencimentos da carreira jurídica de Delegado de Polícia que perduram até hoje, mesmo com o advento da Lei n. ${ }^{\mathrm{o}}$ 12.830/2013 art. $2^{\mathrm{o}}$.

\section{Problemas do Controle feito pelo Ministério Público}

O manto justificador do controle externo da atividade policial, especificamente das atividades das Polícias Judiciárias $^{12}$, teve uma interpretação peculiar adotada e sistematica-

11 A Resolução n.․ 07/2005 de 18 de outubro estabelece: Art. $1^{\circ}$ É vedada a prática de nepotismo no âmbito de todos os órgãos do Poder Judiciário, sendo nulos os atos assim caracterizados. Disponível em: http://www.cnj.jus.br/images/stories/docs_cnj/ resolucao/rescnj_07.pdf. Visitado em 10.07.2017.

$12 \mathrm{O}$ atribuição para o exercício dos atos de Polícia Judiciária é clara e explícita no texto da Constituição Federal que, ao tratar do Departamento de Polícia Federal, lhe garante exclusividade nas funções de polícia judiciária da União (art.144 $\S 1^{\underline{a}}$ inciso IV CF/1988), assim a constituição, ao atribuir funções institucionais, delimita seu exercício à forma exclusiva e privativa, aquela indelegável e está delegável, sendo exclusiva a atividade que somente pode ser realizada ou praticada pelo detentor 
mente aplicada pelos Ministérios Públicos Estaduais e da União com graves consequências à investigação criminal uma vez que: a) fortaleceu a ingerência do Poder Executivo; $\boldsymbol{b}$ ) afastou a apreciação da matéria do Poder Judiciário em toda a sua dimensão; $c$ ) invadiu competência expressa constitucionalmente ${ }^{13} \mathrm{e}$, assim, criou-se um sistema seletivo no qual os fatos a serem apurados são selecionados e tratados por resoluções expedidas pelos Conselhos Nacionais de forma a limitar as atividade das Polícias Judiciárias.

\subsection{INGERÊNCIA DO PODER EXECUTIVO}

A atual forma de controle externo da Polícia Judiciária, exercida apenas pelo Ministério Público, sofre a influência direta do Poder Executivo, tratando-se de um indesejável retrocesso histórico, uma vez que, apesar da expressa vedação constitucional dotada de eficácia plena e aplicabilidade imediata imposta aos seus integrantes de exercer, ainda que em disponibilidade, qual-

da autoridade ou competência para fazê-lo, em detrimento das demais instituições (ALMEIDA 2013: 62-64).

13 A Constituição Federal de 1988 desde a sua promulgação prevê que compete a Polícia Federal exercer com exclusividade as funções de Polícia Judiciária da União (art.144 I $\S 1^{\circ}$ IV - CF/1988) neste sentido, é a manifestação da Advocacia Geral da União, na Ação Direta de Inconstitucionalidade n. ${ }^{\circ}$ 4220, assim: "O Poder Constituinte, ao tempo que concedeu atribuição institucional ao Ministério Público na promoção de procedimentos investigatórios e inquisitórios na proteção de direitos difusos e coletivos - todos de natureza civil e outorgou às Polícias Federal e Civil a competência para o exercício das atividades de polícia judiciária". [...] É conhecida nas letras jurídicas a tese - geralmente defendida por membros do Ministério Público - segundo a qual a função investigatória criminal seria um "poder implícito" outorgado pela Lei Magna ao órgão ministerial, uma vez que a ele foi conferida a competência de requisitar diligências investigatórias e a instauração de inquérito policial, bem como a atribuição de exercer o controle externo da atividade policial, abrindo-lhe espaço, implicitamente, para a realização direta de tais atividades. No entanto, tal interpretação revela-se em descompasso com a literalidade dos dispositivos constitucionais referidos. Em verdade, sabe-se que a interpretação literal não é suficiente para a total apreensão do fenômeno normativo, sendo certo que Savigny já alertava sobre a necessidade de que tal método fosse conjugado com outros meios interpretativos (interpretação sistemática, histórica, teleológica, dentre outras). Sabe-se, ademais, que a moderna hermenêutica assevera que a norma não é pressuposto do labor interpretativo, mas o seu resultado. Consoante Friedrich Müller, autor da teoria estruturante do Direito, o texto da Constituição ou da lei é "apenas a ponta do iceberg normativo". 
quer outra função pública, (artigo $128 \S 5^{\circ}$ II “ $\mathrm{d}$ ” da CF/1988), a norma não vem sendo cumprida desde sua promulgação, é comum observar membros dos Ministérios Públicos ocupando cargos indicados pelos chefes do executivo, mormente de Secretário de Segurança Pública em diversos Estados da Federação com possibilidade de patente intervenção nas atividades policiais sem a devida isenção.

Ao exercer cargo no Poder Executivo, o membro do Ministério Público passa a atuar:

[...] como subordinado ao Chefe da Administração, o que fragiliza a instituição, Ministério Público, tornando-a potencial alvo de captação por interesses políticos e de submissão dos interesses institucionais a projetos pessoais de seus próprios membros ${ }^{14}$.

O controle externo assim exercido fortalece a ingerência do Poder Executivo e serve como instrumento de manutenção do modelo econômico brasileiro de interdependência das relações público-privadas, fundada na matriz patrimonialista, originária do período colonial e aprimorada no imperial, dispunha ao detentor do poder (monarca ou soberano) a disposição legítima e divina dos bens públicos como próprios, sendo a matriz mantida com o advento da república no modelo neopatrimonialista, e, que os detentores do poder (latifundiários, coronéis, oligarcas ou empreiteiros), se apoderam das instituições policiais, judiciais e eleitorais como garantia do poder e da impunidade em substituição ao monarca ${ }^{15}$.

14 Neste sentido é o voto do E. Relator Ministro Gilmar Mendes Medida Cautelar na Arguição de Descumprimento de Preceito Fundamental n.ำ 388 /DF Disponível em: http://www.stf.jus.br/portal/processo/verProcessoAndamento.asp?numero=388\&clas $\mathrm{se}=\mathrm{ADPF} \&$ origem $=\mathrm{AP} \&$ recurso $=0 \&$ tipoJulgamento $=\mathrm{M}$ Visitado em 10.07.2016.

15 A evolução das matrizes do patrimonialismo ao neopatrimonialismo e o conceito de apoderamento das instituições de Estado é desenvolvida no texto Isenção Política na Polícia Federal: A autonomia em suas dimensões administrativa, funcional e orçamentaria. Revista Brasileira de Ciências Policiais Edição Especial Vol. 6 n.2 JulDez de 2015 disponível em: https://periodicos.pf.gov.br/index.php/RBCP/article/ 
A Polícia Judiciária tem sua origem no Brasil Império, e foi criada pela Lei de 15/1827, na qual as funções de investigação estavam atribuídas aos magistrados (Juízes de Paz), entretanto não tardou para, em 1841, com a reforma do Código de Processo Criminal, subordinar as ações judiciárias e policiais ao GovernoGeral e assim possibilitar o controle da fiscalização das atividades econômicas de forma seletiva, ao facilitar a ação dos traficantes e atravessadores no comércio negreiro e restringir as demais atividades econômicas, reforçando a matriz patrimonialista do Estado brasileiro fundada na necessidade de se manter impenetrável e impermeável o círculo de comando do núcleo dirigente na conformação das políticas públicas e na ação dos partidos políticos ao redor do clientelismo a características mais marcantes do Brasil arcaico, uma vez que "o clientelismo se manteve forte no decorrer de períodos democráticos, não definhou durante o período de autoritarismo, não foi extinto pela industrialização e não demonstrou sinais de fraqueza no decorrer da abertura política" (NUNES, 2003: 33-34)

A manutenção do jogo do poder, atualmente, encontra-se lastreada de forma mais retórica, em argumento interpretativo no qual o "princípio mais importante de interpretação é o da unidade da Constituição enquanto unidade de um conjunto com sentido teleológico, já que a essência da Constituição consiste em ser uma ordem unitária da vida política e social da comunidade estatal"16 sendo possível identificar o movimento pendular de maior ou menor subordinação ao Poder Executivo conforme se observa:

1aㅗ (1988/2006): desde a promulgação da Constituição Federal em 5 de outubro de 1988, havia o entendimento doutrinário que todos os ingressantes em data anterior pode-

viewFile/383/247, Visitado em 10.07.2016.

16 Conforme indicado por Luís Roberto Barroso em Interpretação e aplicação da Constituição: fundamentos de uma dogmática constitucional transformadora. São Paulo, Saraiva, 1999, pág. 147. 
riam exercer cargos no executivo, tese que ganha reforço



2a (2006/2016): a possibilidade já utilizada doutrinariamente é estendida a todos os integrantes dos Ministérios Públicos, indistintamente, à vista de interpretação sistêmica da disposição constitucional do exercício de outras funções que lhe forem conferidas, desde que compatíveis com sua finalidade institucional (artigos 128, § 5으, II, "d", e 129, IX CF/1988) firmada com a Resolução n.o

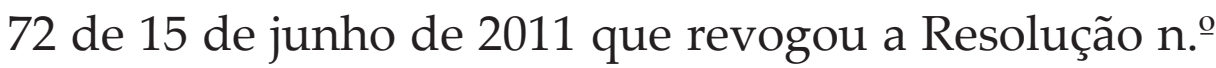
5/2006 - CNMP17.

3모 (2016-...): a Arguição de Descumprimento de Preceito Fundamental n. ${ }^{\circ}$ 388/2016 STF estabelece a inconstitucionalidade da interpretação conjugada dos artigos 128, $\S 5^{\circ}$, II, "d", e 129, IX CF/1988 e declara a inconstitucionalidade da Resolução 72/2011 CNMP, entretanto, de

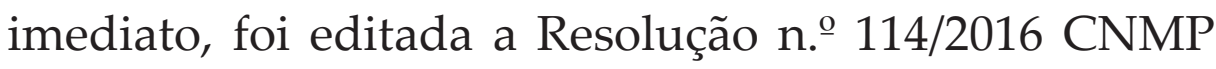
que revogou a mesma e restaurou expressamente a vigência da Resolução n. o 05/2006 possibilitando o entendimento inicial ${ }^{18}$.

A reinterpretação de norma constitucional expressa e o afastamento da sua aplicabilidade por força de Resolução editada por Conselho Nacional possibilita aos membros do parquet ministerial o exercício de cargos na administração pública, dando margem aos detentores do poder por via oblíqua interferirem no andamento e conteúdo das investigações das Polícias Judiciárias tanto da União quanto dos Estados federativos, através

17 No mesmo sentido, no Procedimento de Controle Administrativo (PCA) 381/201350, durante a $3^{\underline{a}}$ Sessão Ordinária do CNMP, o conselheiro relator Cláudio Portela considerou possível, em tese, o afastamento do membro do MP para exercício de função pública em órgão diverso do $\mathrm{MP}$ "à vista de interpretação sistêmica da Constituição, particularmente da conjugação dos artigos 128, § 5º, II, “d”, e 129, IX", que dispõem sobre a disponibilidade de membros do MP exercerem outras funções que lhe forem conferidas, desde que compatíveis com sua finalidade.

18 Disponível em: http://www.cnmp.mp.br/portal_2015/images/Normas/Resolucoes/ Resoluo_144.pdf. Visitado em 10.07.2016. 
dos seus secretários e ministros, e assim determinar o que pode, o que não pode e o que será investigado, tudo sob a égide do clientelismo subserviente.

\subsection{SELETIVIDADE NA INVESTIGAÇÃO}

A seletividade das investigações é possível uma vez que a capacidade de investigar, ou seja, realizar atos de Polícia Judiciária foi indevidamente apropriada por integrantes dos Ministérios Públicos em patente ruptura com o texto constitucional que estabelece a competência e a atribuição específica da Polícia Federal, instituída por lei como órgão permanente, organizado e mantido pela União e estruturado em carreira, e destinada, dentre outras atividades, a exercer, com exclusividade, as funções de Polícia Judiciária da União, (art. 144 I $1^{\mathrm{o}}$ IV - CF/1988), de simples interpretação literal.

A invasão de competência constitucional é instituída por meio da Resolução n.o 13/2006 - CNMP que disciplina o Procedimento Investigatório Criminal PIC dotado da "finalidade apurar a ocorrência de infrações penais de natureza pública, servindo como preparação e embasamento para o juízo de propositura, ou não, da respectiva ação penal" (art. $1^{\mathfrak{0}}$ ), é reproduzir o preceito da Resolução n. - 77/2004 do Conselho Superior do Ministério Público Federal (CSMPF) que regulamenta o Estatuto do Ministério Público da União (Lei Complementar n. . 75/1993) ao dispor neste que no "exercício de suas atribuições, o Ministério Público da União poderá, nos procedimentos de sua competência" (art.8ํ) realizar tais atos.

A falta de transparência é observada em todos os momentos de condução do Procedimento Investigatório Criminal PIC, em seus vários aspectos de legalidade, assim:

a) Prazo: apensar de estabelecer o prazo para a conclusão das investigações de 90 (noventa) dias, a própria resolução permite ao membro do Ministério Público, responsável 
pela sua condução, a possibilidade de sucessivas prorrogações, por igual período, determinando apenas que a decisão seja fundamentada (art.12), sem, entretanto, prever qualquer forma de fiscalização direta do mesmo;

b) Controle: não existe qualquer obrigatoriedade de controle permanente, apenas prevê que os registros sejam mantidos atualizados para eventual conhecimento dos órgãos superiores efetuado de forma restrita com obrigatoriedade de justificativa (art. $12 \S 1^{\circ}$ e $2^{\circ}$ ), inexiste um controle ou acompanhamento periódico das investigações;

c) Arquivamento: "se o membro do Ministério Público responsável pelo procedimento investigatório criminal se convencer da inexistência de fundamento para a propositura de ação penal pública, promoverá o arquivamento dos autos ou das peças de informação, fazendo-o fundamentadamente" (art.15) estando o controle do arquivamento adstrito à estancia superior ou câmara de coordenação da própria instituição.

Trata-se na verdade de um procedimento de investigação criminal preliminar sem a instauração de Inquérito Policial, o que a jurisprudência majoritária já reconheceu como incompatível com a norma legal ${ }^{19}$, neste sentido, o próprio Ministério Público Federal tem entendimento consolidado, expresso de forma definitiva através da $2^{a}$ Câmara Criminal MPF/DF, com a seguinte ementa, in verbis:

EMENTA: Investigações Policiais Preliminares - (IPP), realizadas pela Polícia Federal. I - Ausência de embasamento legal. Procedimento contrário à lei e ao estado de direito. II -

19 A jurisprudência já consolidou tal entendimento em diverso julgados, como TJ-DF - RMO: 1306237620068070001 DF 0130623-76.2006.807.0001 Ementa: PROCEDIMENTO DE INVESTIGAÇÃO PRELIMINAR POLICIAL. ILEGALIDADE. INCOMPATIBILIDADE COM A NORMA LEGAL. NECESSIDADE DE INSTAURAÇÃO DE INQUÉRITO POLICIAL. http://www.jusbrasil.com.br/ jurisprudencia/busca?q=PROCEDIMENTO+DE+INVESTIGA $\%$ C3\%87\%C3\%83O+PR ELIMINAR+POLICIAL. Visitado em 10.07.2016. N este sentido também TJ-DF : RMO $20060111306232 \mathrm{DF}$. 
As investigações policiais devem ser instrumentalizadas em inquéritos policiais, conforme previsto em lei. III - Cabe ao Ministério Público o controle externo da atividade policial (art. 129, inciso VII CF c/c art. 9o e 10o da Lei Complementar $n^{-}$75, de 20 de maio de 1993) devendo este proceder à sistemática verificação dos livros de registros e documentos policiais. IV - Parecer pela recomendação à Polícia Federal, para que esta proceda à revogação dos dispositivos regulamentadores das investigações policiais preliminares. ${ }^{20}$

A seletividade da investigação criminal encontra-se explicitamente prevista na resolução disciplinadora do Procedimento de Investigação Criminal e franqueia aos membros dos Ministérios Públicos, a possibilidade de apurar a ocorrência de infrações penais de natureza pública, sem qualquer controle, podendo investigar o que lhe aprouver ou interessar, em um cenário em que se representa pela instauração de Inquérito Policial para investigar uma nota falsa de pequeno valor, esta destinada a Polícia Judiciária da União, e detém para si a investigação de desvio de verbas públicas envolvendo chefe da administração ou agente político ao qual esteja vinculado e ao final possa arquivar tal procedimento, com embasamento no juízo de propositura, ou não, da respectiva ação penal.

20 A matéria foi tratada no Processo no 3917/95-39 (Protocolo no 015864/95-61 Oficio nº

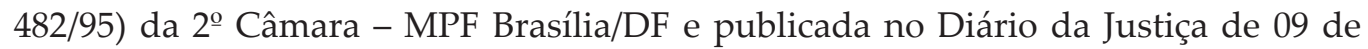
Outubro de 1995 e trata da investigação preliminar, objeto de análise inclusive da Corregedoria Geral da Polícia Federal, nos Pareceres no 003/1996 e 005/1995 - SELP/ DPJ/CCJ, que concluíram pela revogação da Instrução Normativa no 001/DG/DPF de 30 de Outubro de 1992, mesmo prevendo que a Investigação Policial Preliminar IPP era instrumento excepcional destinado a verificar a procedência de notícias de infração penal levadas ao conhecimento da autoridade policial, mas que, pela escassez de indícios, não justifiquem, de imediato, a instauração de inquérito, prevendo inclusive sua forma de instauração e controle pelo chefe da delegacia (interna) e pelos representantes do Ministério Público (externa) no livro de registro próprio, sendo editada a Instrução Normativa nº 11/2001 - DG/DPF, de 27 de Junho de 2001, define e consolida as normas operacionais para execução da atividade de Polícia Judiciária no âmbito do Departamento de Polícia Federal. 


\subsection{AFASTAMENTO DO CONTROLE DO PODER JUdiciário}

O problema central de tal concentração de poder gravita na possibilidade de se afastar, do controle jurisdicional, as atividade de investigação efetuadas por membros do Ministério Público em patente ruptura a todo o ordenamento jurídico fundado em garantias constitucionais especificamente equilibradas onde a lei não excluirá da apreciação do Poder Judiciário, lesão ou ameaça a direito (Art.5., XXXV, CF/1988), consagrado no plano internacional pela Declaração Universal dos Direitos do Homem (1948; Art. 10), Convenção Europeia para a Salvaguarda dos Direitos do Homem e das Liberdades Fundamentais (1950; Art. 6o, inciso I) e Pacto Internacional de Direitos Civis e Políticos (1966; Art. 14, inciso I), bem como no plano regional por meio da Convenção Interamericana sobre Direitos Humanos (1969; Art. 8º, inciso I).

O ordenamento jurídico pátrio, regrado por resoluções inconstitucionais, cria distorções lastreadas nas premissas do Ministério Público ser o detentor do dominus litis na ação penal pública, destinatário final das investigações levadas a cabo pela Polícia Judiciária da União e deter o controle externo da atividade policial (art. 129 incisos I c/c VII CF/1988) o que seria viável no modelo constitucional inicial sem as distorções anteriores de subordinação ao Poder Executivo e capacidade investigativa, ambas coroadas com o afastamento do controle do Poder Judiciário por meio do:

a) Travamento: as normas previstas na Resolução n..$^{\circ}$ 63/2009 - CNJ cujo teor é repetido na Resolução n. ${ }^{\circ}$ 107/2010 do Conselho Superior do Ministério Público Federal - colidem com a expressa disposição legal do Código de Processo Penal, que determina o pronto encaminhamento ao Poder Judiciário das investigações criminais contidas na determinação processual de que encerradas após a Autoridade Policial elaborar minucioso re- 
latório, (art. $\left.10 \S 1^{\circ}\right)$, entretanto a combinação dos dispositivos da Resolução n. . 63/2009 criam uma situação ilegal, uma vez que concluído o Inquérito Policial, e se este já houver sido devidamente registrado nas Varas Federais competentes, será encaminhada para a apreciação do membro do Ministério Público Federal (art.1o c/c $2^{\circ}$ ), possibilitando a este a eternização das investigações por intermédio de pedidos sucessivos de novas diligências escudados na alegação de serem as mesmas imprescindíveis ao oferecimento da denúncia (art. 16 - (PP), mesmo em face da necessária fundamentação constitucional das requisições ministeriais (art.129 VIII - CF/1988), a matéria não nunca seria apreciada pelo Poder Judiciário.

b) Arquivamento: conforme anteriormente apontado, seus membros estão sujeitos ao controle da estancia superior ou câmara de coordenação da própria instituição, e quando o arquivamento é proposto pelo Procurador Geral de Justiça ou da República, nas ações penais originárias não estará sujeito a nenhuma forma de controle conforme jurisprudência consolidada do Suprem Tribunal Federal: "Ação penal originária - Pertencendo ela ao Procurador-Geral da República, e não existindo acima dele outro membro do Ministério Público, uma vez que a suprema chefia deste lhe cabe, não depende, a rigor, de deliberação do Tribunal o arquivamento requerido." (STF - Inq. - Rel. Min. Cordeiro Guerra - RTJ 73/1 $)^{21}$

21 O Supremo Tribunal Federal apresenta um conjunto jurisprudencial consolidado: Pertencendo a ação penal originária ao Procurador-Geral da República, e não existindo acima dele outro membro do Ministério Público, uma vez que a suprema chefia deste lhe cabe, não depende, a rigor, de deliberação do Tribunal o arquivamento requerido. (STF - Inq. - Rel. Min. Luiz Gallotti - RT 479/395); Ação penal originária - Pertencendo ela ao ProcuradorGeral da República, e não existindo acima dele outro membro do Ministério Público, uma vez que a suprema chefia deste the cabe, não depende, a rigor, de deliberação do Tribunal o arquivamento requerido. (STF - Inq. - Rel. Min. Cordeiro Guerra - RTJ 73/1) e Inquérito - Arquivamento. Requerido o arquivamento do processo pelo Procurador-Geral da República, não cabe ao STF examinar o mérito das razões em que o titular único e último do dominus litis apóia seu pedido. (STF - Inq. - Rel. Min. Francisco Rezek - j. 26/06/85 - RT 608/447), 
As medidas apontadas possibilitam que parte dos integrantes dos Ministérios Públicos possam eternizar as investigações, com cotas sucessivas ou mesmo no arquivamento prematuro, prescindindo do Inquérito Policial e da investigação da Polícia Judiciária, sob o manto da ausência de justa causa para o prosseguimento, gerando a insegurança jurídica, neste sentido destaco a Promoção de Arquivamento do Procurador Geral da Justiça na Notícia de Fato n. ํㅜ 1.00.000.004878/201472 destinada a apurar supostas irregularidade na operação de compra pela Petrobrás da refinaria de petróleo "Pasadena Refining System Inc." localizada no Texas (EUA), de propriedade da companhia belga Astra Oil Trading Inc de 22 de junho de 2014, nos seguintes termos:

Portanto, ainda que esteja diante de uma avença mal sucedida e que importou, aparentemente, em prejuízos à companhia, não é possível imputar o cometimento de delito de nenhuma espécie aos membros do Conselho de Administração, mormente quando comprovado que todas as etapas e procedimentos referentes ao perfazimento do negócio foram seguidos.

Destacando que tal entendimento foi proferido sem a devida investigação e instauração do Inquérito Policial, presidido por Delegado de Polícia, objetivando a reunião os elementos necessários à elucidação dos fatos. ${ }^{22}$

destacando-se que nada pode ser feito conforme se observa do seguinte julgado: Admite-se a ação penal privada subsidiária em casos de desídia ou inércia do representante do Ministério Público, que não pode ser considerada como ocorrida no caso de arquivamento da representação determinado pelo Procurador-Geral da Justiça, por entender inexistir justa causa para a ação. (RT 613/431).

22 A matéria encontra-se disciplinada no Regimento Interno do Supremo Tribunal Federal em seu Art. 230-c estabelece in verbi: Instaurado o inquérito, a autoridade policial deverá em sessenta dias reunir os elementos necessários à conclusão das investigações, efetuando as inquirições e realizando as demais diligências necessárias à elucidação dos fatos, apresentando, ao final, peça informativa. Atualizado pela Emenda Regimental n.o 44/2011. 


\section{Conclusões}

O controle externo da atividade de Polícia Judiciária efetuado pelos representantes dos Ministérios Públicos Estaduais e da União, nos moldes como vem sendo desenvolvido, não atende aos preceitos constitucionais originariamente concebidos, uma vez que a própria instituição incumbida de tal tarefa deturpou e desvirtuou tal possibilidade, impossibilitando-a sob o ponto de vista ético-legislativo, uma vez que:

(1) No âmbito interno, ao exercer atividade de Polícia Judiciária o Ministério Público estaria exercendo tal função livre de qualquer controle, não se submeteria à Corregedoria Geral da Polícia no âmbito da fiscalização funcional e técnica das suas atividades;

(2) No âmbito externo, tal controle não mais existiria por ser o próprio Ministério Público Federal órgão responsável pelo mesmo, inviabilizando assim qualquer ato de imparcialidade, pois o autocontrole não é nem moral, nem tampouco, eticamente atingível;

(3) O arquivamento irrecorrível ou recorrível ao próprio chefe da instituição ministerial sem a intervenção do judiciário é medida que possibilita de um lado o arbítrio e de outro poderá fomentar a impunidade;

(4) A ingerência do Poder Executivo como subordinado ao Chefe da Administração, conforme apontado fragiliza a instituição, Ministério Público, tornando-a potencial alvo de captação por interesses políticos e de submissão dos interesses institucionais a projetos pessoais ou a serviço da impunidade e da corrupção;

(5) A investigação por Procedimento de Investigação Diverso propicia uma seletividade que pode afastar a efetiva investigação de problemas sérios afetos à administração pública como a corrupção, para atentes a interesses partidários ou do administrador público de ocasião; 
(6) As normas contidas nas resoluções analisadas afrontam expressamente a Constituição Federal por colidir com as normas de Direito Processual Penal ao tratar de matéria de competência privativa da União (art. 22 inciso I, CF/1988), independente do debate da natureza do Inquérito Policial ${ }^{23}$, uma vez que a norma afrontada encontra-se inserida em dispositivo processual, bem como os Conselhos Nacionais não tem poder de atuação para fora de suas instituições, não sendo, portanto dotados de capacidade legislativa (art. CF/1988).

Assim a tramitação direta, a investigação por Procedimento de Investigação Diverso com seletividade de escolha e capacidade de arquivamento, a possibilidade de ingerência do Poder Executivo face a seus membros ocuparem cargos na administração pública e o afastamento do controle jurisdicional do Poder Judiciário impossibilitam e retiram a legitimidade do Ministério Público para o exercício imparcial do controle externo das atividades de Polícia Judiciária, e o transforma em uma instituições opaca à luz e ao controle externo de toda a sociedade e refratária ao primado da transparência pública e prestação de contas (accountability).

A Polícia Judiciária é uma das instituições com o maior monitoramento de suas atividades uma vez que conta com:

(i) o controle interno: das Corregedorias de Polícia no âmbito da fiscalização funcional e técnica das suas atividades típicas;

23 Inquérito Policial tem natureza processual: (a) Interpretação Teleológica: a Exposição de Motivos do Código de Processo Penal (Decreto-Lei n.ํ 3.689/1914) manteve o Inquérito Policial como processo preliminar e preparatório da ação penal,..., garantia contra apressados e errôneos juízos, formados quando ainda persiste a trepidação moral causada pelo criาme, ou antes, que seja possível uma exata visão do conjunto dos fatos, nas suas circunstâncias objetivas e subjetivas, em um sistema que assegura uma justiça menos aleatória, mais prudente e serena; (b) Interpretação Sistemática e Literal: iniciado com o Auto de Prisão em Flagrante (art.5ำ inciso I c/c 304 CPP) a própria Constituição Federal atribui este caráter de processo legal ao estabelecer no artigo $5^{\circ}$ inciso LXI ninguém será preso senão em flagrante delito e inciso LIV ninguém será privado da liberdade sem o devido processo legal, logo o preso está privado de sua liberdade, entretanto nos casos previstos a Autoridade Policial poderá arbitrar fiança. 
(ii) o controle externo: efetuado pelo Poder Judiciário no plano procedimental e jurisdicional e da Ordem dos Advogados face ao caráter contraditório do Inquérito Policial ${ }^{24}$, além dos controles exercidos pelo Tribunal de Contas da União e da Controladoria Geral da União na administração do orçamento institucional,

Portanto a melhor solução para um efetivo controle externo seria a criação de um Conselho Nacional de Polícia ${ }^{25}$, bem como, em razão da natureza jurisdicional e contraditória das suas atividades de investigação criminal, melhor seria incluir a Polícia Judiciária como Funções Essenciais à Justiça ${ }^{26}$.

\section{REFERÊNCIAS Bibliográficas}

BAROSSO, Luís Roberto (1999) Interpretação e Aplicação da Constituição: fundamentos de uma dogmática constitucional transformadora. São Paulo: Saraiva.

DAHL, Robert A. (1997) Poliarquia: Participação e Oposição. São

24 A Constituição Federal de 1988 não apenas recepcionou como fortaleceu as características processual, jurisdicional e contraditória do Inquérito Policial, o que desde então vem sendo reafirmado expressamente com a nova redação ao artigo 306 do Código de Processo Penal estabelecido pela Lei n.. $11.449 / 2007$, que determina a comunicação da prisão em flagrante de indiciado for hipossuficiente à Defensoria Pública, na edição da Súmula Vinculante n.․ 15/2009 - É direito do defensor, no interesse do representado, ter acesso amplo aos elementos de prova que, já documentados em procedimento investigatório realizado por órgão com competência de polícia judiciária, digam respeito ao exercício do direito de defesa, e na recente reforma do Estatuto da Advocacia e a Ordem dos Advogados do Brasil (OAB) promovida pela Lei n.․ 13.245/2016.

25 Tramita no Congresso Nacional a Proposta de Emenda Constitucional PEC n. ${ }^{\text {o 381/2009 }}$ destinada a criação do Conselho Nacional de Policia com a participação difusa de diversos órgão e a sociedade civil, tratando-se de um verdadeiro instrumento de controle institucional das atividades de Polícia Judiciária: http://www.camara.gov.br/ proposicoesWeb/fichadetramitacao?idProposicao $=439700$ Consultado em 07.10.2015.

26 Neste sentido destaco o estudo de Eliomar da Silva Pereira em Introdução às Ciências Policiais: A Polícia entre a Ciência e Política, editora Almedina. (2015: 70) e a posição de Jacinto Nelson de Miranda em parecer do Conselho Federal da Ordem, disponível em http://www.oab.org.br/editora/revista/users/revista/1211292337174218181901. pdf. Consultado em 07.10.2015. 
Paulo: Ed. EDUSP.

HABERMAS, Jüngen. (1996) Between Facts and Norms:

Contributions to a Discourse Theory of Law and Democracy. EUA: MIT Press.

MELO, Marcus André. (2007). O viés majoritário na política comparada: responsabilização, desenho institucional e qualidade democrática. Revista Brasileira de Ciências Sociais, 22(63), 11-29.

NUNES, Edson. (2003) Gramática Política do Brasil: clientelismo e insulamento burocrático. Rio de Janeiro: Jorge Zahar Editor.

OFFE, C. (2001) How can we trust on fellow citizens? In WARREN, Mark. Democracy and trust. Cambridge: Cambridge University Press.

PERSSON, Torsten. GERARD, Roland. e GUIDO, Tabellini. (1997) Separation of Powers and Political Accountability. Em Quarterly Journal of Economics 112: 1163-1202.

SCHEDLER, Andreas. (1999) In: Andreas Schedler, Larry Diamond, Marc F. Plattner. The Self-Restraining State: Power and Accountability in New Democracies. London: Lynne Rienner Publisher.

WERNER, Guilherme C. (2015) Isenção Política na Polícia Federal: A autonomia em suas dimensões administrativa, funcional e orçamentaria. Revista Brasileira de Ciências Policiais Edição Especial Vol. 6 n.2 Jul-Dez de 2015. Sitio: https://periodicos.pf.gov.br/index.php/RBCP/article/ viewFile/383/247 